\title{
Bizygomatic Width and its Association with Social and Personality Traits in Males
}

\author{
Distancia Bicigomática y su Asociación con Habilidades Sociales \\ y Rasgos de Personalidad en Hombres
}

Julián Gabarre-Mir¹; José B. Navarro-Pastor²; Cristina Gabarre-Armengol ${ }^{1}$ \& Santiago Estaún-Ferrer ${ }^{3}$

GABARRE-MIR, J.; NAVARRO-PASTOR, J. B.; GABARRE-ARMENGOL, C. \& ESTAÚN-FERRER, S. Bizygomatic width and its association with social and personality traits in males. Int. J. Morphol., 35(3):1037-1042, 2017.

SUMMARY: This study will examine how differences in measurements between bizygomatic and bigonial arches of the human face can provide relevant information regarding personality and abilities of the subject. Sample: 82 males. Group A: 55 subjects with the bizygomatic arch in contraction. Group B: 27 subjects without the bizygomatic arch in contraction. Subjects performed self-assessment tests in the following areas: ability incorporating themselves into the group, alexithymia and emotional expressiveness. Group A showed greater self-sufficiency and independence than group B, greater difficulty in describing and verbally expressing their emotions, less ability to express themselves emotionally through other forms of communication and reduced willingness to cooperate philanthropically. Results suggest a strong relationship between morphological structure of the bizygomatic arch and certain psychological characteristics.

KEY WORDS: Bizygomatic width; Craniofacial; Personality; Alexithymia; Prospective ex post facto study.

\section{INTRODUCCIÓN}

Since Gall's publication (Gall, 1835) there has been a persistent interest in finding a direct relationship between the temperamental, behavioral, emotional, moral and ethical traits of an individual and their physical appearance, particularly centered upon the craniofacial shape. There is little scientific literature studying straightforward connections between behavioral and psychological traits and facial appearance. There is research treating birth disorders and syndromes (Kelly et al., 2005; Jones, 2007), where specific morphogenetic variants relating to the different disorders and syndromes has been found. Non-pathological studies have found associations between the forehead angle and impulsivity (Guerrero et al., 2016) or the more studied maxillary width-to-height ratio (fWHR) as a marker for male dominance (Stirrat et al., 2012; Valentine et al., 2014).

The shape of the brain can be predicted from the craniofacial shape (Richtsmeier \& Flaherty, 2013) and from the early stages of neurodevelopment shows a special interconnection with the face (Kjaer, 1995). The prenatal face and brain, both stem from the same layer of the notochord, the ectoderm, and both structures occur within a very close time span of one another (Donovan-Lepore $e t$ $a l ., 2006)$, finding that the face is essentially supported by the growing brain which undergoes extensive morphogenetic changes (Diewert \& Lozanoff, 1993).

Corman (1970) observed that areas of the face that were in expansion (wider) were related to extroversion, interest/motivation, the need of affirmation and hyposensitivity, and contracted areas were related to inhibition, disinterest/non-motivation, less need of affirmation, and hypersensitivity. He divided the face into three levels for analysis and gave to each face level width an area of interest (Fig. 1) and proposed that each face level interacts with the others and it can only be evaluated in comparison with the others (or at least with one other level). This proposal matches MacLean's hypothesis of the triple brain (1970 and 1990), later supported by research in Neuropsychology (Rains, 2004), Embriology (Kjaer) and the mainly accepted idea among scientists that more neural tissue means greater computational capacity (Goldberg,

\footnotetext{
${ }^{1}$ Institute of Craniofacial Psychology, Barcelona, Spain.

${ }^{2}$ Department of Psychobiology and Methodology, Universitat Autònoma de Barcelona, Bellaterra, Spain.

${ }^{3}$ Department of Basic, Evolutive and Educational Psychology, Universitat Autònoma de Barcelona, Bellaterra, Spain.
} 
2002). The scientific literature has found a close relationship between emotions and the different areas of the limbic system at different ages (Suzuki et al., 2013; Bartholomeusz et al., 2014), which is contained behind the maxillary area. The aim of this paper is to study the influence of the maxillary width (bizygomatic arch), when compared to the mandibular width (bigonial arch), on the individual's approach to socio-emotional aspects, such as the need for interaction with others (independence/gregariousness) or the ability or lack thereof to express emotions (expressiveness/alexithymia).

\section{MATERIAL AND METHOD}

The present study meets the ethical standards and has been approved by the University Ethical Committee (CEEAH - Universitat Autònoma de Barcelona). In addition, we had the written consent of the participants, provided that the results were anonymous. Nevertheless, there were no ethical violations in testing the subjects underwent, nor were they subjected to any physical or psychological harm.

Participants. The total sample consisted of 82 subjects. The average age was 38.07 years (10.66). Everyone was of an adult age and in good health and all signed a document of consent agreeing to participate in the study which included tests, evaluations, photographs and measurements for research purposes only.

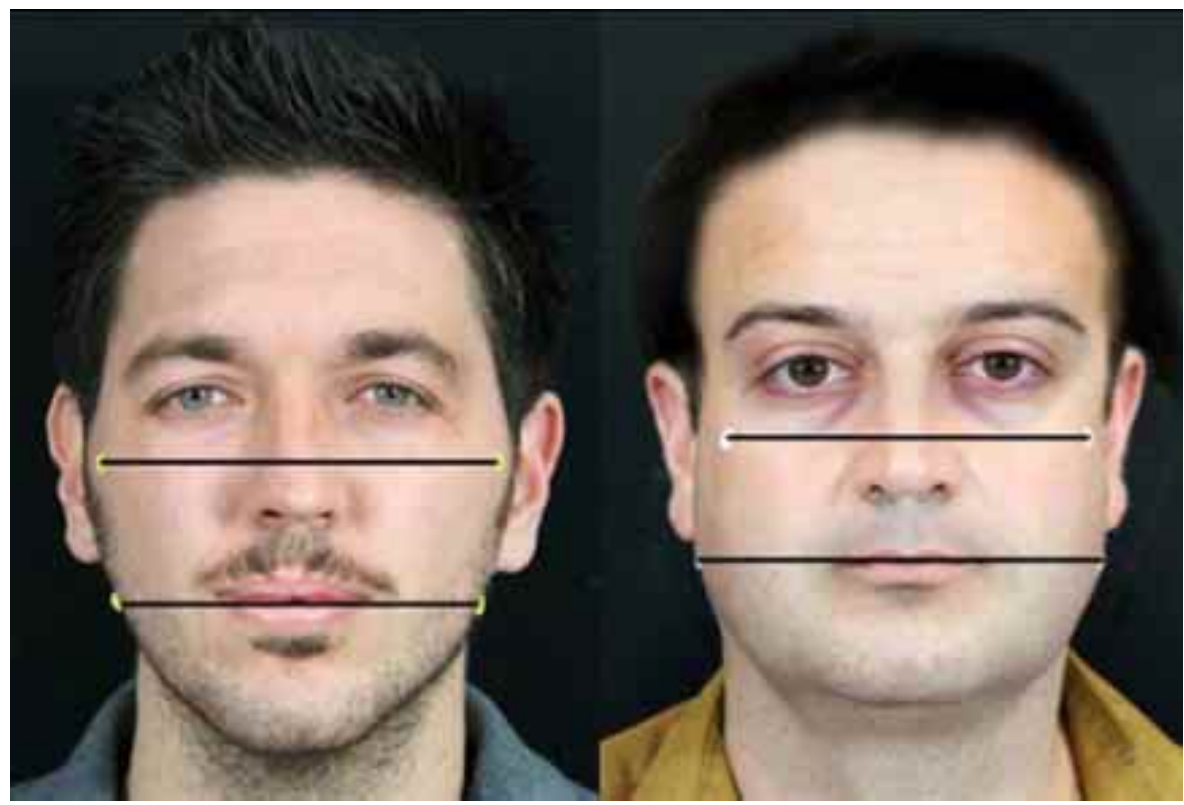

Fig. 2. Group A with contracted bizygomatic arch (right) and Group B, with expanded bizygomatic arch (left). [1] Zygion (Zy) is the most lateral point of each zygomatic arch. It is identified by physical palpation. [2] Gonion (Go) is the most lateral point of the mandibular angle. It is identified by physical palpation.

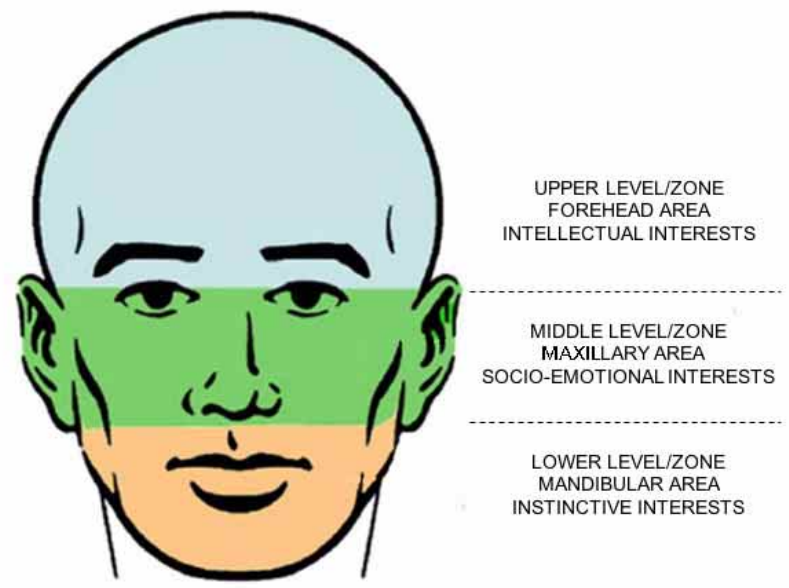

Fig. 1. Levels/Zones of the face - Areas of interest

Participants were divided into two groups according to their bizygomatic arch characteristics (Fig. 2).

- Group A, (bizygomatic arch in contraction): Distance between Zy's[1] at least $0.5 \mathrm{~cm}$. narrower than distance between Go's[2] (55 subjects).

- Group B, (bizygomatic arch in expansion): Distance between Zy's at least $0.5 \mathrm{~cm}$ wider than distance between Go's (27 subjects).

In order to determine which subjects were to participate in the study searches were carried out in a large shopping center of Barcelona. For three days, three independent collaborators asked passers-by at a designated entrance, to participate in the study.

Those who accepted had their bizygomatic and bigonial arches measured in situ, using calipers (see in Instruments and procedure). The volunteers that meet the criterion of minimum difference $(0.5 \mathrm{~cm})$ were included in the study. Of the 116 who initially agreed to participate, 87 met the inclusion criteria. These subjects were given an appointment to proceed with the testing in the near future at the Institute of Craniofacial Psychology. Five of the 87 

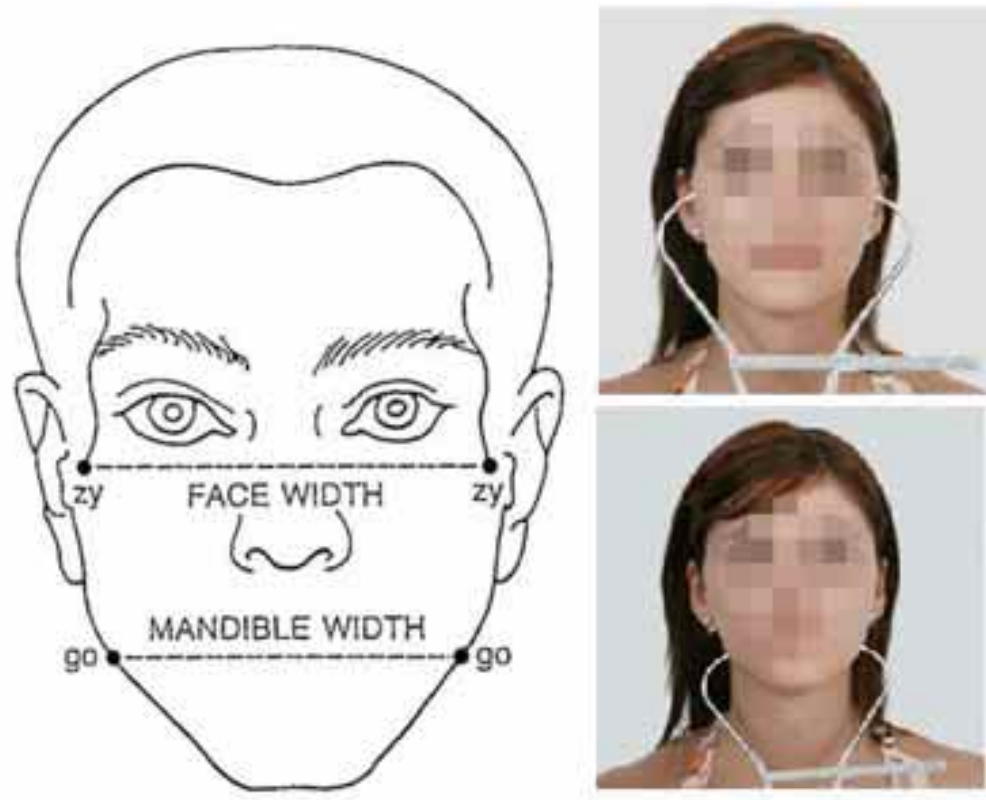

Fig. 3. Faciall measurements with compass/calipers.

volunteers did not come to proceed with the testing. The final size of our sample consisted of 82 subjects.

Instruments. Once participants were classified as belonging to one group or another and their participation confirmed, they were given the following tests in the order shown below:

Anthropometric measurements: Using calipers and following the methodology developed by Farkas (1994) the distance was again measured between anthropometric points $\mathrm{Zy}$ and compared that with the measurement of the distance between anthropometric points Go (Fig. 3). With the help of an assistant the distance Zy-Zy and Go-Go were measured twice, the mean of these two readings being the final figure used. The maximum observed discrepancy between the two measurements was $1 \mathrm{~mm}$.

Photometric Measurements: To take measurements of the distances (Zy-Zy and Go-Go), using photometry and ImageJ software version 1.42q (Rasband, 2009) standardized digital photographs of the subjects were taken with a Canon 400 D Digital using a $17-85 \mathrm{~mm}$ lens, fixed to a height adjustable tripod at a fixed distance of $1.5 \mathrm{~m}$ from the individual to be photographed. The same $67 \mathrm{~mm}$ zoom was always used and two halogen spot lights were fixed on a black background to avoid any shadows appearing in the photographs. Each subject was seated in a chair of fixed height and placed in the same position and a wall mounted support held the head in the correct position. Those wearing glasses were asked to remove them and all subjects were encouraged to maintain a neutral and relaxed facial expression.
Visual assessment: For a total period of 15 hours, two judges were trained as observers in the visual assessment of morphological types (group A and group B).

Each judge viewed the subjects as they were sat facing them and always from the same distance. The judges were given sufficient time to conduct the analysis and afterwards the resulting scores for each subject were noted on a template. The possible scores were $-3,-2,-1$, $0,+1,+2,+3$. The maximum positive score $(+3)$ indicated that the subject had maximum retraction in the mid zone of the face, while the maximum negative score $(-3)$ indicated a minimum retraction in the mid zone of the face. A score of zero indicated that the judges observed no difference between the width of the mid zone of the face and the mandible / jawbone. In order to verify that both judges had been properly trained, their level of agreement in the classification of subjects belonging to group A or B was calculated, giving a kappa value $=0.63(\mathrm{p}<0.0005)$ which is considered good (Landis \& Koch, 1977).

Psychological evaluation instruments: Each subject was subjected to 5 psychological assessment tests:

- Personality Factor Questionnaire - 16PF, version adapted to Spanish (Seisdedos et al., 1989). The Q2 factor was used, which measures the subject's ability to incorporate himself into and work within a group plus their level of selfsufficiency.

- Attitudes and cognitive strategies - AECS (Moraleda et al., 2004). The Apathy-Withdrawal scale was used which corresponds to the category of Social Attitude.

- Personality Inventory Pedagogical Institute "Saint Georges" using the Sociable Misanthropic scale - Inv. SG (Université de Montréal, 1971).

- Toronto Alexithymia Scale (TAS-20) for the Spanish sample (Moral de la Rubia \& Retamales, 2000).

- Emotional Expressivity Scale (EES) (Kring et al., 1994).

Procedure. Statistical analysis was done using SPSS 19 (2010). For agreement in participant's classification in the two defined groups, the Kappa index was used. The agreement between quantitative measures was calculated 
with the intraclass correlation coefficient for absolute agreement (ICC). For comparison of the two groups in psychological measures, analysis of covariance was employed, with age as adjusting variable. In this last analysis effect size was obtained through Cohen's D. With a type I error probability of 0.05 and the estimates obtained using our sample size, we obtained a statistical power of 0.82 for detecting differences greater than 2 points in $16 \mathrm{PF}$.

\section{RESULTS}

Descriptive results of demographical, facial and psychological measures are presented in Table I.

Before doing any statistical test the normality of the variables in each group was tested employing Shapiro-Wilk test and visual examination of box-plots. All the variables showed Gaussian distributions with insignificant deviations from normality.

The concordance in the classification in the two groups from the visual, anthropometric and photographic information was absolute $($ Kappa $=1)$. The ICC for the difference between Zygonions and Gonions obtained with anthropometric and photographic procedures was 0.978 (CI95 \% 0.957 to 0.987).

Table II shows the comparison of psychological measures between groups. Raw differences (Group A minus Group B) are first presented, followed by adjusted differences by age. All the comparisons are very significant from a statistical point of view, with lower limits for confidence intervals very far from zero value. Cohen's D values are very large, ranging from 1.16 to 5.26 .

Table I. Description of demographical, facial and psychological measures.

\begin{tabular}{|c|c|c|c|c|c|c|}
\hline & \multicolumn{3}{|c|}{ Group $\mathrm{A}-\mathrm{n}=55$} & \multicolumn{3}{|c|}{ Group $B-n=27$} \\
\hline & Mean & St.Dev. & Min./Max. & Mean & St.Dev. & Min./Max. \\
\hline Age & 35.67 & 10.38 & $20 / 58$ & 39.25 & 10.69 & $19 / 66$ \\
\hline $\begin{array}{l}\text { Anthropometric } \\
\text { Zy-Zy distance }(\mathrm{mm})\end{array}$ & 137.05 & 7 & $120 / 146$ & 124.38 & 6.52 & $105 / 137.5$ \\
\hline $\begin{array}{l}\text { Anthropometric } \\
\text { Go-Go distance (mm) }\end{array}$ & 129.50 & 7.20 & $116 / 142.5$ & 147.40 & 9.36 & $125 / 173$ \\
\hline $\begin{array}{l}\text { Anthropometric distance } \\
\text { difference }(\mathrm{mm})\end{array}$ & -7.74 & 5.19 & $-20.50 /-5$ & 22.68 & 5.63 & $10 / 36$ \\
\hline Photographic & 137.74 & 7.16 & $122 / 150$ & 126.89 & 7.09 & $109 / 141$ \\
\hline $\begin{array}{l}\text { Zy-Zy distance }(\mathrm{mm}) \\
\text { Photographic } \\
\text { Go-Go distance }(\mathrm{mm})\end{array}$ & 130.29 & 7.71 & $117 / 143$ & 147.85 & 9.52 & $129 / 171$ \\
\hline $\begin{array}{l}\text { Photographic distance } \\
\text { difference }(\mathrm{mm})\end{array}$ & -7.44 & 4.88 & $-19 / 0$ & 20.6 & 6.29 & $8 / 37$ \\
\hline $16 \mathrm{PF}$ & 12.37 & 2.77 & $6 / 17$ & 30.51 & 3.43 & $22 / 36$ \\
\hline AECS & 22.22 & 7.35 & $10 / 38$ & 43.18 & 9.69 & $18 / 61$ \\
\hline Inv.SG & 18.89 & 4.3 & $6 / 25$ & 7.91 & 4.29 & $0 / 17$ \\
\hline TAS-20 & 42.37 & 11.12 & $23 / 62$ & 56.62 & 12.89 & $31 / 79$ \\
\hline EES & 74.07 & 13.62 & $42 / 97$ & 49.24 & 16.7 & $25 / 97$ \\
\hline
\end{tabular}

Table II. Raw and adjusted comparison of groups in psychological measures.

\begin{tabular}{|c|c|c|c|c|c|}
\hline \multirow[t]{2}{*}{$\mathrm{N}=82$} & \multirow{2}{*}{$\begin{array}{l}\text { Raw results } \\
\text { Mean Diff. }\end{array}$} & \multicolumn{4}{|c|}{ Adjusted results ${ }^{*}$} \\
\hline & & Mean Diff.** & $\mathrm{p}$ & $95 \% \mathrm{CI}$ & Cohens'D \\
\hline $16 \mathrm{PF}$ & 18.14 & 18.06 & $<.0005$ & 16.52 to 19.6 & 5.26 \\
\hline AECS & 20.96 & 21.23 & $<.0005$ & 16.96 to 25.5 & 2.23 \\
\hline Inv.SG & -10.98 & -11.49 & $<.0005$ & -13.45 to -9.53 & 2.64 \\
\hline TAS -20 & 14.25 & 14.97 & $<.0005$ & 9.17 to 20.77 & 1.16 \\
\hline EES & -24.83 & -26.40 & $<.0005$ & -33.59 to -19.21 & 1.64 \\
\hline
\end{tabular}

* Adjusted by age ** Group A minus group B 


\section{DISCUSSION}

A high degree of correspondence has been found between visual, anthropometric and photometric measurements used to measure the bizygomatic and bigonial arch widths. Although it is necessary to conduct more studies of this type, these results support the idea that it is possible to use any of these measurement methods, when dealing with bizygomatic and bigonial arch measurements.

Regarding the comparison of groups with previously assessed psychological characteristics, subjects with the bizygomatic arch in contraction (group A) were more selfsufficient and showed less inclination to join in with the group. They also displayed a reluctance or reduced ability to describe and express their emotions and had greater difficulty displaying these emotions outwardly compared with the subjects with the bizygomatic arch in expansion (group B).

Subjects with a facial morphology with the bizygomatic arch in contraction are more independent and display a reduced capacity to join in with a group compared with the group of subjects who have the bizygomatic arch in expansion; the latter cooperated more readily and found it easier to connect with the group. To illustrate this, let us look at the standardized test $16 \mathrm{PF}$ percentiles obtained by the 55 subjects in the test group, which would appear to be sufficiently revealing: the vast majority of subjects $(85.2$ $\%$ ) were in the 10 percentile and the rest were between 8 and percentile 9 .

The sample shows a trend towards the contraction of the bizygomatic arch width, which highlights the possibility of this being a more common trait among men. In our sample the contraction of the bizygomatic arch showed a significant correlation with higher scores of alexithymia, which has also been previously identified as a more prevalent symptom among men than among women (Levant et al., 2009).

Besides the most studied facial width-to-hight ratio (fWHR) (Stirrat et al.; Valentine et al.), the variable taken in this study (width differences between bizygomatic and bigonial arches) seem to be another good marker to be taken into consideration in further research.

Limitations to our study included a relatively small sample size and consequently the generalization of our results; however, the data gained from the study shows a strong correlation between anthropometrical measurements and psychological variables. In addition, we did not take into account additional elements of the face described by
Corman as moderator variables and do not know their effect on the studied correlations, although the results show a strong relation between the bizygomatic arch and the pychological traits defined above. This strong relationship is confirmed with the high values of the Cohen's D.

To our knowledge this paper is one of the first studies that shows a correlation between the comparison of bizygomatic and bigonial arch widths and some socioemotional aspects and personality traits. Viewing the results carefully, the data shown suggests that craniofacial structure can predict some personality traits, opening up the possibility of continuing with this methodology to address in a future, more in-depth studies, the relationship between the face and other personality traits.

GABARRE-MIR, J.; NAVARRO-PASTOR, J. B.; GABARREARMENGOL, C. \& ESTAÚN-FERRER, S. La anchura bicigomática y su asociación con habilidades sociales y rasgos de personalidad en hombres. Int. J. Morphol., 35(3):1037-1042, 2017.

RESUMEN: Este estudio examina cómo la diferencia entre las anchuras del arco bicigomático y bigonial en la cara humana, proporcionan información relevante sobre la personalidad y las habilidades de un sujeto. Muestra: 82 hombres. Grupo A: 55 sujetos con el arco bicigomático en contracción. Grupo B: 27 sujetos con el arco bicigomático sin retracción. Los sujetos realizaron pruebas de autoevaluación en las siguientes áreas: adhesión/independencia al grupo, alexitimia y expresividad emocional. El grupo A mostró respecto al grupo B una mayor autosuficiencia e independencia, mayor dificultad para describir y expresar verbalmente sus emociones, menor capacidad para expresarse emocionalmente a través de diferentes formas de comunicación y reducción de la voluntad de cooperar filantrópicamente. Los resultados sugieren una fuerte relación entre la estructura morfológica del arco bicigomático y ciertas características psicológicas.

PALABRAS CLAVE: Anchura bicigomática; Craneofacial; Personalidad; Alexitimia; Estudio Ex Post Facto Prospectivo.

\section{REFERENCES}

Bartholomeusz, C. F.; Whittle, S. L.; Pilioussis, E.; Allott, K.; Rice, S.; Schäfer, M. R.; Pantelis, C. \& Amminger, G. P. Relationship between amygdala volume and emotion recognition in adolescents at ultra-high risk for psychosis. Psychiatry Res., 224(3):159-67, 2014.

Corman, L. Nuevo Manual de Morfopsicología. Alcoy, Editorial Marfil, 1970.

Diewert, V. M. \& Lozanoff, S. A morphometric analysis of human embryonic craniofacial growth in the median plane during primary palate formation. J. Craniofac. Genet. Dev. Biol., 13(3):147-61, 1993.

Donovan-Lepore, A. M.; Jaeger, J.; Czobor, P.; Abdelmessih, S. \& Berns, S. M. Quantitative craniofacial anomalies in a racially mixed schizophrenia sample. Biol. Psychiatry, 59(4):349-53, 2006. 
Farkas, L. G. Anthropometry of the Head and Face. $2^{\text {nd }}$ ed. New York, Raven Press, 1994.

Gall, F. J. On the Functions of the Brain and of Each of Its Parts: with Observations on the Possibility of Determining the Instincts, Propensities, and Talents, or the Moral and Intellectual Dispositions of Men and Animals, by the Configuration of the Brain and Head. Boston, Marsh, Capen \& Lyon, 1835.

Goldberg, E. El Cerebro Ejecutivo. Barcelona, Editorial Crítica, 2002.

Guerrero, D.; Gabarre-Armengol, C.; Navarro, J. B. \& Gabarre-Mir, J. Impulsivity and its association with the slant of the forehead. Int. J. Morphol., 34(3):990-6, 2016.

Jones, K. L. Patrones Reconocibles de Malformaciones Humana. $6^{\mathrm{a}}$ ed. Madrid, Elsevier Saunders, 2007.

Kelly, B. D.; Lane, A.; Agartz, I.; Henriksson, K. M. \& McNeil, T. F. Craniofacial dysmorphology in Swedish schizophrenia patients. Acta Psychiatr. Scand., 111(3):202-7, 2005.

Kjaer, I. Human prenatal craniofacial development related to brain development under normal and pathologic conditions. Acta Odontol. Scand., 53(3):135-43, 1995.

Kring, A. M.; Smith, D. A. \& Neale, J. M. Individual differences in dispositional expressiveness: development and validation of the Emotional Expressivity Scale. J. Pers. Soc. Psychol., 66(5):934-49, 1994.

Landis, J. R. \& Koch, G. G. The measurement of observer agreement for categorical data. Biometrics, 33(1):159-74, 1977.

Levant, R. F.; Hall, R. J.; Williams, C. \& Hasan, N. T. Gender Differences in Alexithymia. Psychol. Men Masc., 10(3):190-203, 2009.

Moral de la Rubia, J. \& Retamales, R. Estudio de validación de la Escala de Alexitimia de Toronto (TAS-20) en muestra española. Rev. Electron. Psicol. [revista en Internet] 4(1):art3, 2000. Available at: http:// www.psiquiatria.com/psicologia/vol4num1/art_3.htm).

Moraleda, M.; González, A. \& García-Gallo, J. AECS: Actitudes y Estrategias Cognitivas Sociales: Manual. $2^{\mathrm{a}}$ ed. Madrid, TEA Ediciones, 2004.

Rains, G. D. Principios de Neuropsicología Humana. Madrid, McGrawInteramericana, 2004.

Rasband, W. S. ImageJ (Computer Program) U.S. National Institutes of Health, 2009. Available at: http://rsb.info.nih.gov/ij/

Richtsmeier, J. T \& Flaherty, K. Hand in glove: brain and skull in development and dysmorphogenesis. Acta. Neuropathol., 125(4):469$89,2013$.

Seisdedos, N.; Cordero, A.; González, M. \& De la Cruz, M. V. 16 PF, Cuestionario Factorial de Personalidad: Adaptación Española. Madrid, TEA Ediciones, 1989.

SPSS Inc. Statistical Package for Social Sciences 19.0.0. New York, IBM, 2010.

Stirrat, M.; Stulp, G. \& Pollet, T. V. Male facial width is associated with death by contact violence: narrow-faced males are more likely to die from contact violence. Evol. Hum. Behav., 33(5):551-6, 2012.

Suzuki, H.; Botteron, K. N.; Luby, J. L.; Belden, A. C.; Gaffrey, M. S.; Babb, C. M.; Nishino, T.; Miller, M. I.; Ratnanather, J. T. \& Barch, D. M. Structural-functional correlations between hippocampal volume and cortico-limbic emotional responses in depressed children. Cogn. Affect. Behav. Neurosci., 13(1):135-51, 2013.

Université de Montréal, Instituto Pontificio San Pío X. Inventario de la Personalidad. Salamanca. Ediciones Instituto Pontificio San Pío X, 1971.

Valentine, K. A.; Li, N. P.; Penke, L. \& Perret, D. I. Judging a man by the width of his face: the role of facial ratios and dominance in mate choice at speed-dating events. Psychol. Sci., 25(3):806-11, 2014.

\author{
Corresponding author: \\ Julián Gabarre \\ Institute of Craniofacial Psychology \\ c/ Pau Clarís 120, 3 2 08009 \\ Barcelona \\ SPAIN
}

E-mail: info@craniofacialpsychology.com

Received:12-12-2016

Accepted: 05-04-2017 